\title{
Corrective effects of benzodiazepine derivative - diazepinone on purine and lipid metabolism in the liver of rats with Parkinson's disease
}

\author{
I. Ya. Shtanova ${ }^{1,2}$, P. I. Yanchuk ${ }^{1}$, S. P. Veselsky ${ }^{1}$, O. V. Tsymbalyuk ${ }^{1}$, T. V. Vovkun ${ }^{2}$, \\ V. S. Moskvina ${ }^{2}$, O. V. Shablykina ${ }^{2}$, A. A. Kravchenko ${ }^{3}$, V. N. Baban'1, V. P. Khilya ${ }^{2}$ \\ ${ }^{1}$ Institute of High Technologies, Taras Shevchenko National University of Kyiv; \\ ${ }^{2}$ Faculty of Chemistry, Taras Shevchenko National University of Kyiv; \\ ${ }^{3}$ Chuiko Institute of Surface Chemistry, National Academy of Sciences; e-mail: shtanova@ukr.net
}

\begin{abstract}
Parkinson's disease (PD) is a neurodegenerative disorder characterized by the loss of dopaminergic neurons in the substantia nigra. The cause of PD is not fully understood, and effective treatments still do not exist. It is believed that oxidative stress, mitochondrial dysfunction, and impaired lipid metabolism may underlie the pathogenesis of PD. Bile contains the breakdown products of various compounds that form in hepatocytes. This study aimed to evaluate the effect of a new benzodiazepine derivative - diazepinone (DP) on purine and lipid metabolism in the liver of rats with PD caused by rotenone (ROT) by studying the composition of bile. The concentration of ATP, ADP, AMP, xanthine, hypoxanthine, phospholipids (PL), cholesterol (CHOL), cholesterol esters (ECHOL), free fatty acids (FFA), and triglycerides (TG) was quantified in bile samples by thin-layer chromatography. Our findings suggested that the ratio of AMP/ $A T P$ in bile increased almost threefold under the influence of ROT, and with DP, it exceeded the norm by only 1.6 times. ROT also increased the content of xanthine and hypoxanthine by $28.6 \%(P<0.001)$ and $66.7 \%(P<0.01)$, respectively. DP did not affect the increased xanthine content relative to control but significantly reduced the level of hypoxanthine (up to $22.2 \%, P<0.05$, above normal). In addition, ROT reduced the content of bile PL, CHOL, ECHOL, TG by 23.9\% $(P<0.001), 38.6 \%(P<0.001), 47.5 \%$ $(P<0.001), 39.2 \%(P<0.001)$, respectively. Under the influence of the DP, all the above indicators returned to the level of control. Thus, diazepinone improves both the metabolism of purines and lipids in the liver of rats with ROT-simulated PD. This drug may become a therapeutic agent for treating PD and possibly other neurodegenerative diseases in the future.
\end{abstract}

Keywords: rotenone; Parkinson's disease; liver; purine metabolism; lipid metabolis; bile.

\section{INTRODUCTION}

Parkinson's disease (PD) is a neurodegenerative disorder involving progressive loss of dopaminergic neurons in the substantia nigra and blue spot. The first is responsible for motor control, and the second - for various psychological effects. One of the most critical consequences of neuronal degeneration is a gradual reduction of dopamine (DA) synthesis. The etiology of PD has not been clearly defined, but numerous studies suggest that increased exposure to free radicals, combined with mitochondrial dysfunction, might play an essential role in dopaminergic neurons death [1]. Risk factors for PD are age, heredity, sex, and exposure to toxins: herbicides and pesticides. The risk of PD increases with age, and as the population ages, Parkinsonism can become a significant problem for humanity. Like many other diseases, animal models have played an important role in elucidating various aspects of the pathomechanism of PD. Most of these models use toxins that affect mitochondrial function, including rotenone (ROT), a pesticide that is a potent inhibitor of mitochondrial complex I. ROT inhibits mitochondrial oxidative phosphorylation and causes cell death

(C) 1.Ya. Shtanova, P.I. Yanchuk, S.P. Veselsky, O.V. Tsymbalyuk, T.V. Vovkun, V. S. Moskvina, O.V. Shablykina,

A.A. Kravchenko, V. N. Baban, V. P. Khilya 
[2]. It has been shown that ROT provides an excellent model of PD in rodents under conditions of chronic administration in low doses. It was found that chronic infusions of ROT cause selective degeneration of nigrostriatal dopaminergic neurons and the formation of $\alpha$-synuclein structures, accompanied by signs of parkinsonism [3]. The death of substantia nigra neurons causes the impairment of voluntary motor control; therefore, the primary clinical signs and symptoms of PD are rest tremor, rigidity, hypokinesia, bradykinesia, akinesia, postural instability. In addition, several non-motor symptoms complicate the life of patients. In part, cognitive impairment, sleep disorders, hyposmia (olfactory deficits), visual abnormalities (oculomotor disturbances), urogenital dysfunction, depression, as well as emotional disorders such as fear, anxiety, apathy, and anhedonia often accompany PD [4]. Recently, several treatment strategies have emerged to facilitate PD and improve the quality of patients' life. PD is mainly treated with levodopa, a precursor to DA, and agonists of DA receptors. Currently available dopaminergic drugs improve physical performance and increase quality and life expectancy. DA agonists activate the DA receptors, mimicking or copying DA function in the brain; however, they cause several serious side effects, such as dyskinesia, confusion, and hallucinations with long-term use [5]. All modern strategies for treating PD control the symptoms only and can not prevent the progression of the disease because the mechanisms that trigger its development are still not fully understood. In this context, drugs that can modulate mitochondrial dynamics, function, and biogenesis may be used in the future treatment of PD. Studies in clinical and experimental models have shown that metabolic pathways disrupted in PD are mainly related to lipid and energy metabolism $[6,7]$. However, the absolute method of early diagnosis of PD in vivo still does not exist. The diagnosis of PD is based on clinical data confirmed by relevant studies. However, the absolute method of early diagnosis of PD in vivo still does not exist; therefore, the disease is usually detected at later stages when treatment is complicated. Patients with PD do not experience motor symptoms until more than $50 \%$ of the substantia nigra neurons are degenerated [8]. Current research focuses on developing adequate diagnostic methods, searching for biomarkers of the disease, and creating new, more effective treatment strategies for this dangerous disorder. The investigations of recent years demonstrate that in neurodegenerative disorders such as PD, antipsychotic drugs, particularly benzodiazepine derivatives, protect neuronal mitochondria from damage caused by ROT and 6-hydroxydopamine (6-OHDA) [9]. It is known that the functioning of mitochondria in both neurons and hepatocytes does not differ.

The aim of this study was: (i) to explore the liver function of rats with a ROT-induced PD, partially characteristics of purine and lipid metabolism in the liver; (ii) to study the curative effect of a new therapeutic agent derived from benzodiazepines - diazepinone (DP) on the parameters of the purine system and the levels of various lipids in the bile of rats with a rotenone model of PD.

\section{METHODS}

The following reagents were used in this study: ROT, dimethyl sulfoxide (DMSO) were purchased from Sigma (St. Louis, MO, USA). Sodium thiopental (lat. Thiopentalumnatrium) was produced in Ukraine (OAO Kyivmedpreparat). Diazepinone - 4-(Pyridin4-yl)-2H-benzo[d][1,2]diazepin-1(5H)-one. Elemental analysis of Diazepinone (DP) was performed in the analytical laboratory of V.P. Kukhar, Institute of Bioorganic Chemistry and Petrochemistry, NAS of Ukraine, Kyiv, Ukraine [10].

Experimental animals. The study has been done in acute experiments on 60 male mature Wistar rats (obtained from Institute of Pharmacology and Toxicology of the Academy of Medical Sciences of Ukraine (Kyiv, Ukraine), weighing 
190-220 g, 14 weeks old. The animals were housed under standard humidity conditions (55$60 \%)$ in a temperature-controlled environment $\left(22 \pm 2^{\circ} \mathrm{C}\right)$ with a $12 \mathrm{~h} \mathrm{light/dark} \mathrm{cycle,}$ with unlimited access to filtered water and commercial food throughout the experimental period. Animal housing care and the application of experimental procedures were per the existing international requirements and norms of humane attitude toward animals (Strasbourg, 1986, Law of Ukraine dated February 21, 2006, No. 3447IV) and to the decision held by Biological Ethics Committee, Educational and Scientific Centre, Institute of Biology and Medicine, National Taras Schevchenko University of Kyiv (protocol No. 3 from April 9, 2009).

Experimental design. Rats were injected with either ROT $(2.0 \mathrm{mg} / \mathrm{kg}$, intraperitoneally (i.p.)) suspended in sunflower oil $(1 \mathrm{ml} / \mathrm{kg})$ (ROT vehicle) or vehicle alone [11], daily for 28 consecutive days (from 10:00 a.m to 12:00 a.m.). After one week, the rats were randomly divided into six groups: 1 - Control group $(\mathrm{n}=$ 10), rats received an injection of sunflower oil $(1 \mathrm{ml} / \mathrm{kg}$ of body weight) that did not include ROT; 2 - ROT group $(\mathrm{n}=10)$, ROT $(2 \mathrm{mg} /$ $\mathrm{kg}) ; 3-\mathrm{ROT}+1 \%$ solution of DMSO group $(\mathrm{n}=10), \mathrm{ROT}+1 \% \operatorname{DMSO}(1 \mathrm{ml} / \mathrm{kg}) ; 4-$ ROT+DP group ( $\mathrm{n}=10), \mathrm{ROT}+\mathrm{DP}(0.5 \mathrm{mg} / \mathrm{kg})$; $5-\mathrm{ROT}+\mathrm{DP}$ group $(\mathrm{n}=10), \mathrm{ROT}+\mathrm{DP}(1 \mathrm{mg} / \mathrm{kg})$; 6 - ROT+DP group ( $\mathrm{n}=10)$, ROT+DP $(2 \mathrm{mg} / \mathrm{kg})$. Immediately before use, DP was freshly suspended in a $1 \%$ DMSO solution. DP $(0.5$, 1 and $2 \mathrm{mg} / \mathrm{kg})$ or $1 \%$ DMSO $(1 \mathrm{ml} / \mathrm{kg})$, were administrated daily, i.p. as a single dose, for 28 days, starting immediately after the last injection of ROT. The dose had been determined based on the lowest dose of other neuroprotective factors shown to be effective.

\section{Determination of lipids content in bile samples.} According to the set goal, we determined the concentration of the following compounds in the bile (mg\%): phospholipids (PL), cholesterol (CHOL), cholesterol esters (ECHOL), free fatty acids (FFA), triglycerides (TG). Previously, rats were anesthetized with sodium thiopental $(60 \mathrm{mg} / \mathrm{kg})$, and laparotomy was performed. The common bile duct was then cannulated with a polyethylene catheter. Secreted bile was collected every $30 \mathrm{~min}$ during $1 \mathrm{~h}$ of the experiment by a graduated micropipette connected to a cannula located in the bile duct. Bile collected during the first $30 \mathrm{~min}$ was not taken into account (equilibrium period to stabilize the rate of bile outflow). Then the bile was subjected to chemical treatment according to a chosen methodology. Bile lipids were divided by the method of thin-layer chromatography that has been described by Veselsky, et al. [12]. For this purpose, $0.1 \mathrm{ml}$ of bile was added to a $2.4 \mu \mathrm{l}$ mixture of chloroform-methanol (2:1) and $0.5 \mathrm{ml}$ acidified water $(0.5 \mathrm{ml}$ of concentrated sulfuric acid per 1 liter of double-distilled water) was added in $5 \mathrm{~min}$. Samples were kept overnight for complete separation into two phases. The lower phase contained lipids. The extract was dried at $+70^{\circ} \mathrm{C}$. The dry residue was dissolved in $40 \mu \mathrm{l}$ of a chloroform-methanol mixture (3:1) and put on the plate as a thin strip. Chromatography was performed in a chamber saturated by solvent vapor. The system of eluents included petroleum ether, diethyl ether, ether, glacial acetic acid (30:10:0.2). Fractions of biliary lipids were stained with $5 \%$ phosphomolybdic acid in $96 \%$ ethanol, followed by heating at $100^{\circ} \mathrm{C}$ for 5 min. Identification of the major lipid fractions was performed using standards and color of the spots, considering the relative mobility of fractions. For quantitative evaluation of individual fractions of lipids in bile, solutions of their main components $(1 \mathrm{mg}$ of substance per $1 \mathrm{ml}$ of solvent), both individually and in a mixture with specimens of other fractions, were prepared. This mixture of standards is quantitatively (from $1 \mu 1$ to $2 ; 5 ; 10 ; 15 ; 20 ; 25$ and $30 \mu 1)$ adsorbed on chromatographic paper. After extraction and concentration of bile at the bottom of the cone tube, it should be dissolved in $50 \mu \mathrm{l}$ of solvent and dropped a few times with a micropipette $(5 \mu l)$ on the surface of a prepared and marked 
chromatographic plate. Chromatographic separation of lipid components of bile is carried out on "Silufol" plates. After treatment with an aqueous solution of phosphomolybdic acid, a quantitative assessment of the color intensity of each fraction was performed using a densitometer DO-1M ("Shimadzu", Japan, $\lambda$ $620 \mathrm{~nm}$ ). The area of the spot was also measured. The value of the combined test was deposited on the $\boldsymbol{y}$ axis in the calibration graph, and the $\boldsymbol{x}$ axis was marked with the known amount of a corresponding standard - a witness of this lipid fraction's presence. These parameters were evaluated for lipid fractions from samples of the studied bile. The amount of the corresponding lipid was determined in $\mu \mathrm{g}$ based on the calibration curve. Finally, taking into account the dilution and the part of the extract, we determined the amount of lipids in $\mathrm{mg}$ per 100 $\mathrm{ml}$ of bile.

Evaluation of purine metabolites, as well as lipids, was performed by the method of thin-layer chromatography. For this purpose, $0.2 \mathrm{ml}$ of bile was added to $1.8 \mathrm{ml}$ of $0.8 \mathrm{~N}$ perchloric acid $\left(\mathrm{HClO}_{4}\right)$ solution. Both bile and $\mathrm{HClO}_{4}$ were pre-cooled to a temperature of $0-+40^{\circ} \mathrm{C}$. Perchloric acid was used for simultaneous precipitation of bile proteins and adenine nucleotides: ATP, ADP, AMP, xanthine, and hypoxanthine. The obtained protein-free perchlorate extracts were centrifuged for 15 min on an OPn-3 U42 centrifuge at $1500 \mathrm{rpm}$ and neutralized with $\mathrm{K}_{2} \mathrm{CO}_{3}$ to $\mathrm{pH}$ 7.0. After centrifugation under the above conditions, the supernatant was collected, and certain aliquots were applied to the chromatographic plates. Separation and quantification of adenine nucleotides on "Silufol" plates UV-254 was performed by the method of Maidanyuk, et al. [13]. Direct densitometry of the plates in reflected light was performed on a highspeed scanner of the CS-920 densitometer «Shimadzu» (Japan) in the direction of solvent movement at a wavelength of $260 \mathrm{~nm}$. The content of test compounds in chromatographic spots was determined using calibration curves of the spot area on the number of applied chromatographically pure preparations of ATP, ADP, AMP, xanthine, and hypoxanthine.

The results were assessed by: the parametric one-way ANOVA method and also in combination with the Tukey test for posthoc pairwise comparison and $\mathrm{p}$ values less than 0.05 were considered significant; the nonparametric Kruskal Wallis ANOVA method and also in combination with the Mann-Whitney test for pairwise comparison with Bonferroni correction and $\mathrm{p}$ values less than 0.01 were considered significant. Statistical analysis was performed by Origin 2018, and the charts were drawn by Excel software.

\section{RESULTS AND DISCUSSION}

Quantitative determination of purines in the bile of rats. In ROT-treated rats, the concentration of ATP was significantly altered: this index decreased by $38 \%(\mathrm{P}<0.001)$. In the rats of the ROT $+1 \%$ DMSO group, ATP level was not fully restored, but only to $72.8 \%$ of the control $(\mathrm{P}<0.001)$. Meanwhile this index was greater by $17.5 \%(\mathrm{P}<0.01)$ than in the ROT group. In animals with PD that were injected the drug at doses of $0.5,1$ and $2 \mathrm{mg} / \mathrm{kg}$ the ATP indicators were lower than the control by $31.5 \%$ $(\mathrm{P}<0.001), 15.2 \%(\mathrm{P}<0.05)$ and $21.7 \%$ $(\mathrm{P}<0.001)$, respectively. In the groups ROT +1 $\mathrm{mg} / \mathrm{kg}$ DP and ROT $+2 \mathrm{mg} / \mathrm{kg}$ DP bile contained ATP by $36.8 \%$ and $26.3 \%$, respectively, in both cases $\mathrm{P}<0.001$, greater than in the group ROT, and respectively by $16.4 \%$ and $7.5 \%$, in both cases $\mathrm{P}<0.05$, more than in the group ROT $+1 \%$ DMSO. In addition, in the groups ROT $+1 \mathrm{mg} / \mathrm{kg}$ DP and ROT $+2 \mathrm{mg} / \mathrm{kg}$ DP the concentration of ATP in bile, compared with the group ROT +0.5 $\mathrm{mg} / \mathrm{kg}$ DP, was greater by $23.8 \%(\mathrm{P}<0.01)$ and $14.3 \%(\mathrm{P}<0.001)$, respectively.

The content of ADP did not change significantly between different groups and the control group (Table).

The concentration of $A M P$ was higher in the ROT group by $85.7 \%(\mathrm{P}<0.001)$, in the 
$\mathrm{ROT}+1 \% \mathrm{DMSO}$ and ROT+DP $0.5 \mathrm{mg} / \mathrm{kg}$ groups by $100 \%$, in both $\mathrm{P}<0.001$, in the ROT $+\mathrm{DP}$ $1 \mathrm{mg} / \mathrm{kg}$ and ROT+DP $2 \mathrm{mg} / \mathrm{kg}$ groups - only by $35.7 \%(\mathrm{P}<0.01)$ as compared with control animals.

The levels of $A M P$ in the ROT+DP $1 \mathrm{mg} / \mathrm{kg}$ and ROT+DP $2 \mathrm{mg} / \mathrm{kg}$ groups were lower by $26.9 \%(\mathrm{P}<0.05)$ than in the ROT group and by $32 \%(\mathrm{P}<0.05)$ lower than in ROT $+1 \%$ DMSO and ROT+DP $0.5 \mathrm{mg} / \mathrm{kg}$ groups. The values of AMP/ATP ratio are given in the Table.

The concentration of xanthine in the bile of rats increased in comparison with the control rats: in the groups $\mathrm{ROT}$ and $\mathrm{ROT}+1 \% \mathrm{DMSO}$ - in both by $28.6 \%(\mathrm{P}<0.05)$, in the groups ROT+DP $0.5 \mathrm{mg} / \mathrm{kg}$ and ROT+DP $2 \mathrm{mg} / \mathrm{kg}-$ by $57.1 \%(\mathrm{P}<0.001)$ and $42.9 \%(\mathrm{P}<0.001)$, respectively. Only in the group ROT+DP $1 \mathrm{mg} / \mathrm{kg}$ the level of xanthine did not differ from that in control.

The content of hypoxanthine in bile, compared with the control rats, was higher in all groups: in the group of ROT - by $66.7 \%$ $(\mathrm{P}<0.001)$, in the group of ROT $+1 \% \mathrm{DMSO}-$ by $44.4 \%(\mathrm{P}<0.001)$, in the group ROT+DP 0.5 $\mathrm{mg} / \mathrm{kg}$ - by $55.6 \%(\mathrm{P}<0.001)$, in the groups ROT+DP $1 \mathrm{mg} / \mathrm{kg}$ and ROT+DP $2 \mathrm{mg} / \mathrm{kg}-$ in both $22.2 \%(\mathrm{P}<0.05)$. In rats of the ROT $+\mathrm{DP}$ $1 \mathrm{mg} / \mathrm{kg}$ and ROT+DP $2 \mathrm{mg} / \mathrm{kg}$ groups, the concentration of this compound was lower by $26.7 \%(\mathrm{P}<0.01)$ than in the ROT group, by $15.4 \%(\mathrm{P}<0.01)$ than in the ROT $+1 \%$ DMSO group, by $21.4 \%(\mathrm{P}<0.05)$ than in the ROT $+\mathrm{DP}$ $0.5 \mathrm{mg} / \mathrm{kg}$ group (Table).

One of the most important functions of the liver is the formation of bile. Bile is both a secretory and excretory fluid that performs two important functions - the delivery of bile acids to the intestinal tract for digestion and absorption of lipids and excretion from the liver into the intestine of both CHOL and various metabolites - the breakdown products of compounds contained in hepatocytes. Comprehensive analysis of bile in rats with $\mathrm{PD}$ revealed quantitative changes in the lipid composition and purine metabolites associated with this disease, which may contribute to the diagnosis of PD. In addition to the typical motor function disorders in patients with parkinsonism, there is rapid fatigue and weakness - signs of deterioration of energy supply of physiological functions. The latter, in particular, can be confirmed by the accumulation of purine metabolites, such as hypoxanthine, in the blood. Purine metabolism is an important basis for energy metabolism, and the components of the purine system are one of the key metabolites of the last. ATP is a universal source of energy for all biochemical

The effect of diazepinone on the content of purine metabolites in the bile of rats with ROT-induced PD

\begin{tabular}{l|c|c|c|c|c|c|}
\hline Animal group & ATP & ADP & AMP & AMP/ATP & Xanthine & Hypoxanthine \\
control & $9.2 \pm 0.2$ & $1.4 \pm 0.08$ & $0.7 \pm 0.06 ;$ & $0.08 \pm 0.01$ & $0.7 \pm 0.04$ & $0.9 \pm 0.06$ \\
ROT & $5.7 \pm 0.25^{* * *}$ & $1.3 \pm 0.06$ & $1.3 \pm 0.1 * * *$ & $0.23 \pm 0.01$ & $0.9 \pm 0.09 *$ & $1.5 \pm 0.08^{* * *}$ \\
ROT t+1\% & & & & & \\
DMSO & $6.7 \pm 0,2^{* * *}, \# \#$ & $1.6 \pm 0.09 \#$ & $1.4 \pm 0.08^{* * *}, \#$ & $0.21 \pm 0.02$ & $0.9 \pm 0.07 *$ & $1.3 \pm 0.06^{* * *}$ \\
Rot $+0,5 \mathrm{mg} /$ & & & & & \\
$\mathrm{kg}$ & $6.3 \pm 0.1 * * *$ & $1.25 \pm 0.05 \alpha \alpha$ & $1.4 \pm 0.07^{* * *}$ & $0.22 \pm 0.008$ & $1.1 \pm 0.08 * * *$ & $1.4 \pm 0.05^{* * *}$ \\
$\mathrm{ROT}+1 \mathrm{mg} /$ & $7.8 \pm 0.4^{* *}$, & & & & $1.1 \pm 0.05^{*}, \# \#$, \\
$\mathrm{kg}$ & $\# \# \#, \alpha \alpha, £ £ £$ & $1.4 \pm 0.05 £$ & $0.95 \pm 0.05 * * *$ & $0.12 \pm 0.02^{* *}$ & $0.8 \pm 0.05, £$ & $\alpha \alpha, £ £$ \\
ROT $+2 \mathrm{mg} /$ & $7.2 \pm 0.2^{* * *}$, & & $0.95 \pm 0.06^{* * *}$, & & $1.0 \pm 0.05^{* * *}$, & $1.1 \pm 0.07 *, \# \#$, \\
$\mathrm{kg}$ & $\# \# \#, \alpha, £ £ £$ & $1.4 \pm 0.06 £$ & $\#, \alpha, £$ & $0.13 \pm 0.009 * * *$ & $\alpha \alpha \alpha$ & $\alpha, £$ \\
\hline
\end{tabular}

Note: Bile samples were collected every 30 min during $1 \mathrm{~h}$ of the experiment. Means \pm s.e.m.; $\mathrm{n}=10$; $* \mathrm{P}<0.05, * * \mathrm{P}<0.01, * * * \mathrm{P}<0.001$ as compared with control rats; $\# \mathrm{P}<0.05, \# \# \mathrm{P}<0.01, \# \# \# \mathrm{P}<0.001$ as compared with ROT; $\alpha \mathrm{P}<0.05, \alpha \alpha \mathrm{P}<0.01, \alpha \alpha \alpha . \mathrm{P}<0.001$ as compared with ROT $+1 \% \mathrm{DMSO}$ £ $\mathrm{P}<0.05$, $£ £ \mathrm{P}<0.01, £ £ £ \mathrm{P}<0.001$ as compared with $\mathrm{ROT}+\mathrm{DP} 0.5 \mathrm{mg} / \mathrm{kg}$ group. 
processes occurring in living systems. In neurons, mitochondria provide localization of ATP in areas that are particularly demanding of energy supply (including Ranvier interceptions and presynaptic terminals) and buffer cytosolic calcium. These two mitochondrial functions are required for the release and recirculation of synaptic vesicles and the maintenance of electrochemical gradients that are closely interdependent, as both are provided by calcium signal transmission. By performing these important tasks, mitochondria become an integral part of the functioning and survival of neurons. In humans, the lifetime of one ATP molecule is less than $1 \mathrm{~min}$. ATP in the body is almost not stored, and for the normal vital activity, it is necessary to synthesize new ATP molecules [13] constantly. Loss of mitochondrial function inhibits ATP production and calcium buffering, key processes in neuronal function, and increases oxidative stress. ROT has become interesting for PD study because it has high lipophilicity, which allows it to easily penetrate biological membranes, including the blood-brain barrier [14]. As mentioned above, this pesticide acts as a potent inhibitor of mitochondrial complex I, leading to incomplete electron transfer from the centers of iron-sulfur complex I to ubiquinone, which blocks oxidative phosphorylation with limited ATP synthesis [15], promoting the formation of free oxygen radicals and causes oxidative stress and apoptosis in cells. Mitochondrial dysfunction and increased oxidative stress were demonstrated in a subgroup of patients with PD [16]. The link between mitochondrial dysfunction and the production of oxygen free radicals presents mitochondria as a potential target for PD treatment. It should be noted that the level of ATP, ADP, AMP in the blood significantly depends on the functional state of the liver: there is evidence that in alcoholic hepatitis or cirrhotic lesions of this organ, the content of this compound in the blood of patients decreased by 28 and 39\%, respectively [17]. In this aspect, it was interesting to investigate the characteristics of energy metabolism in parkinsonian rats using corrective chemical compounds with targeted chemical modification. We supported that long-term administration of ROT to experimental rats was accompanied by significant alterations in the content of purine metabolites in bile (reduction of ATP content by $38 \%$ ). DP at doses of $0.5,1$, and $2 \mathrm{mg} /$ $\mathrm{kg}$ increased the ATP content by $11.3,36.8$, and $26.3 \%$, respectively, relative to its level reduced under the influence of ROT. Thus, DP significantly restored the content of ATP in bile, indicating an improvement in the biosynthesis of the latter in hepatocytes. The effect of ROT on the level of ADP and AMP in the bile of rats was ambiguous. If the concentration of ADP was close to the control values, the content of AMP in bile under the influence of ROT increased by $85.7 \%$. The latter indicates that in this case, there is an inhibition of ATP resynthesis from ADP, and especially from AMP. In addition to having a corrective effect on ATP levels, DP also involved both ADP and AMP in ATP synthesis, as evidenced by the AMP/ATP ratio, which we determined in different groups. This indicator is an important marker of mitochondrial function in hepatocytes. We found that it has significantly improved under the effect of DP. Concentrations of xanthine and hypoxanthine in bile significantly increased under the influence of ROT. This fact may indicate an increase in catabolic processes in the metabolism of purines in PD and is consistent with the data obtained by other researchers. Sherer, et al. [18] suggested a dose-dependent decrease in ATP content in isolated human neuroblastoma cells under the influence of ROT. They suggested that ROT disrupts the functioning of mitochondria in cells; in other words, it creates conditions similar to those in the brain neurons of patients with PD. On the other hand, Yakhine-Diop, et al. [19] observed an increase in the levels of both hypoxanthine and xanthine in the serum of mice with PD caused by 6-OHDA, similar to the results obtained in patients with PD. All these data show that an increase in the content of xanthine 
and hypoxanthine is a characteristic feature of $\mathrm{PD}$, and the accumulation of hypoxanthine may indicate a blockade in PD enzymatic conversion of hypoxanthine to uric acid (UA), which is the final oxidation product of purine catabolism. This may be the cause of the decreased plasma UA levels observed in most patients with PD. It is noted that UA is a powerful antioxidant and can protect against PD. It is important that in the human liver have been found high levels of UA, and this compound provides more than half of the antioxidant properties of blood plasma [20]. The results indicated that DP at doses of 1 and $2 \mathrm{mg} / \mathrm{kg}$ markedly reduced hypoxanthine content in the bile compared with ROT rats. On the contrary, in the same doses, DP markedly increased the level of xanthine in bile, which does not exclude its direct effect on enzymes involved in the conversion of xanthine to hypoxanthine. The effect of $1 \%$ DMSO on energy metabolism was manifested in a slight increase in bile content of ATP, ADP, and AMP.

Thus, the analysis of the obtained data allows us to conclude that the reproduction of the PD model in rats by ROT is accompanied by significant adverse changes in purine metabolism, namely: the accumulation in the bile of its final products and a significant decrease in ATP content, which is an essential

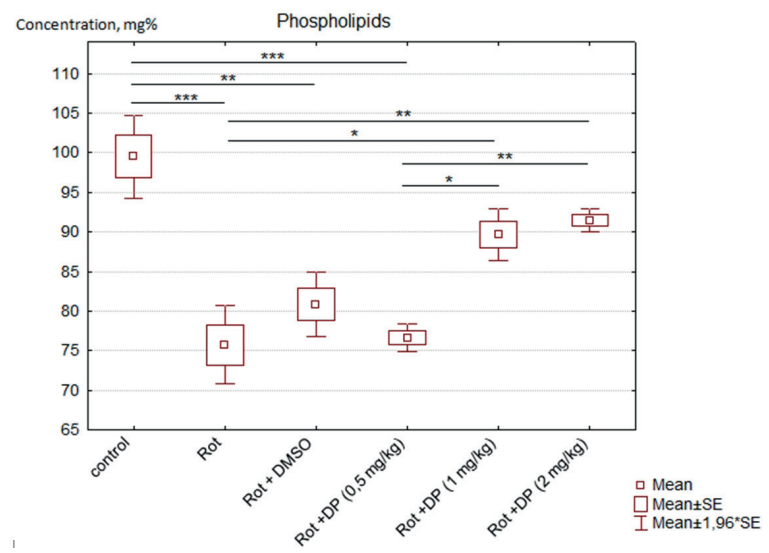

Fig. 1. Effect of DP on the concentration of PL in the bile of rats with ROT-modeled PD. Secreted bile was collected each half-hour during $1 \mathrm{~h}$ of the experiment. Kruskal-Wallis test. $* \mathrm{P}<0.05 ; * * \mathrm{P}<0.01 ; * * * \mathrm{P}<0.001$ substance of energy metabolism. Approbation of DP as a corrective factor in PD showed its ability to effectively restore ATP synthesis, which may indirectly indicate an improvement in mitochondrial biogenesis in liver cells.

Influence of DP on bile lipids content in rats. In ROT-treated rats, the content of most bile lipids has altered. In particular, the concentration of PL decreased by $23.9 \%$ ( $\mathrm{P}<0.001)$. Significant statistical changes were observed in the groups $\mathrm{ROT}+1 \%$ DMSO and ROT+DP $0.5 \mathrm{mg} / \mathrm{kg}$, where the PL level was lower than in the control rats by $18.7 \%(\mathrm{P}<0.01)$ and $23 \%(\mathrm{P}<0.01)$, respectively. As shown in Fig. 1, no significant differences were observed in PL content in rats of ROT+DP $1 \mathrm{mg} / \mathrm{kg}$ and ROT+DP $2 \mathrm{mg} / \mathrm{kg}$ groups as compared with control rats.

Biochemical analysis of bile demonstrated that compared with control data, the content of CHOL diminished under the influence of ROT by $38.6 \%(\mathrm{P}<0.001)$. Similar differences were observed in the CHOL level in ROT $+1 \%$ DMSO, ROT+DP $0.5 \mathrm{mg} / \mathrm{kg}$ groups, which are $25.1 \%$ $(\mathrm{P}<0.05)$ and $28.9 \%(\mathrm{P}<0.01)$, respectively less than under normal conditions. On the other hand, in rats of ROT + DP $1 \mathrm{mg} / \mathrm{kg}$ and $\mathrm{ROT}+\mathrm{DP}$ $2 \mathrm{mg} / \mathrm{kg}$ groups, significant differences with the values of the control group were not observed (Fig. 2).

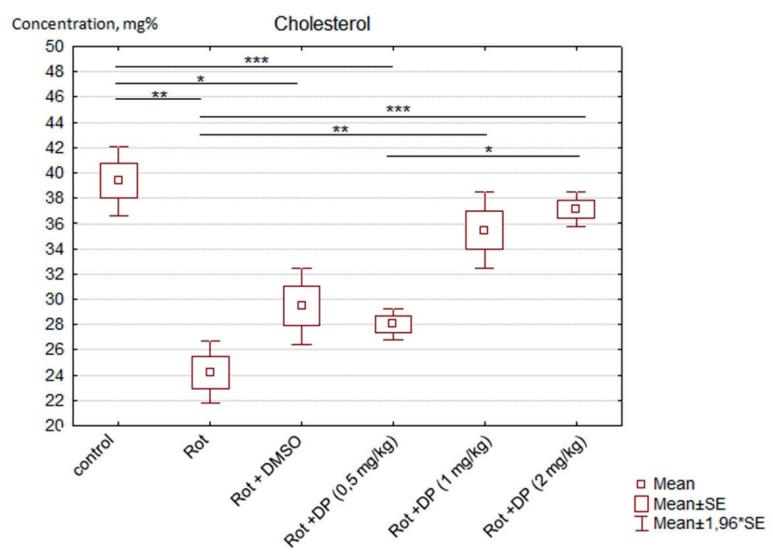

Fig. 2. Influence of DP on the concentration of CHOL in the bile of rats with ROT-modeled PD. ${ }^{*} \mathrm{P}<0.05$; $* * \mathrm{P}<0.01$; $* * * \mathrm{P}<0.001$ 
The current data revealed that under the effect of ROT, the content of ECHOL in groups of ROT $2.0 \mathrm{mg} / \mathrm{kg}$ and $\mathrm{ROT}+1 \% \mathrm{DMSO}$ decreased by $47.5 \%(\mathrm{P}<0.001)$ and by $37.3 \%$ $(\mathrm{P}<0.01)$, respectively in comparison with the control group. DP at a dose of $0.5 \mathrm{mg} / \mathrm{kg}$ did not restore the level of ECHOL in bile, and the last remained less by $37.6 \%(\mathrm{P}<0.001)$ relative to the control group. At doses of DP 1 and $2 \mathrm{mg}$ / $\mathrm{kg}$, recovery of ECHOL content in bile to control values was observed (Fig. 3).

As illustrated in Fig. 4, under the effect of ROT, the level of FFA in the bile relative to control rats did not change in any of the groups (Fig. 4).

Under the effect of ROT, the content of TG changed. This index was significantly decreased by $39.2 \%(P<0.001)$. In animals of all other groups, it did not differ from that in the control group (Fig. 5).

PL, CHOL, and its esters are the main lipids of bile, while the human bile concentration of FFA and TG is small. One of the functions of biliary secretion of PL is to protect cell membranes facing the biliary tree from salts of bile acids. Biliary PL also plays a crucial role in the solubilization of CHOL. Mixed micelles of bile acid salts and PL have a much greater ability to absorb CHOL (1 million times) than simple bile salt micelles.

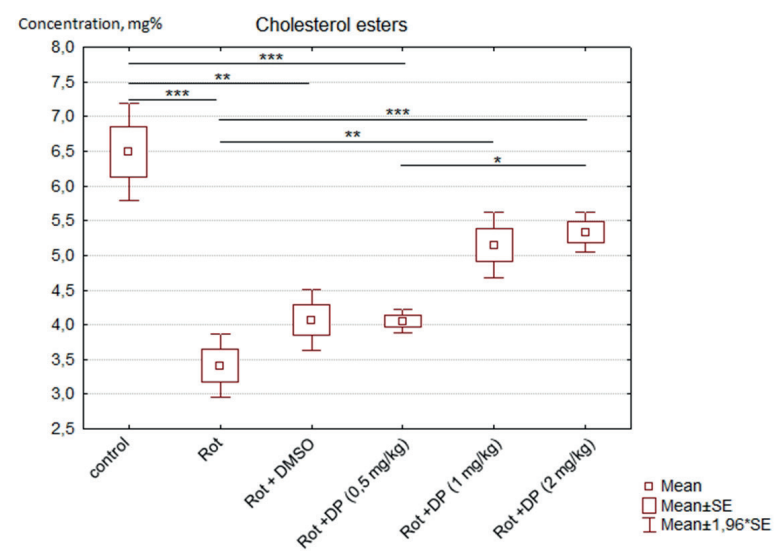

Fig. 3. The content of ECHOL in the bile of rats with ROTmodeled $\mathrm{PD}$ before and after DP administration. $* \mathrm{P}<0.05$, $* * \mathrm{P}<0.01, * * * \mathrm{P}<0.001$
The presence of a phosphoric acid residue in the PL molecule makes it a solvent for CHOL and other hydrophobic compounds [21]. In the present study, we found that the PL content in the bile of rats with PD decreased by almost $24 \%$. Such alterations can lead to substantial impairment in the solubilization of CHOL - a highly hydrophobic compound that is excreted mainly through the bile. The deficiency of PL as the essential component for micelle formation gradually leads to the oversaturation of bile with CHOL and gallstone formation. Thus, a decrease in the production of PL in the liver causes disorders in the formation of bile, which is the primary mechanism for maintaining lipid homeostasis in the body [22]. In addition, as a result of PL deficiency, the permeability of hepatocyte membranes and the accumulation of fat in the liver increases because in the absence of PL, fatty acids (together with glycerin) form a neutral fat that accumulates in hepatocytes, displacing all other components [23]. The presented data revealed that DP at doses of 1 and $2 \mathrm{mg} / \mathrm{kg}$ advantaged to restore the content of PL in bile. This effect was probably not least due to the increase in ATP levels in hepatocytes, which was observed with the application of DP in the same doses because both the synthesis and the transport of PL require significant energy consumption. We believe that the increase in

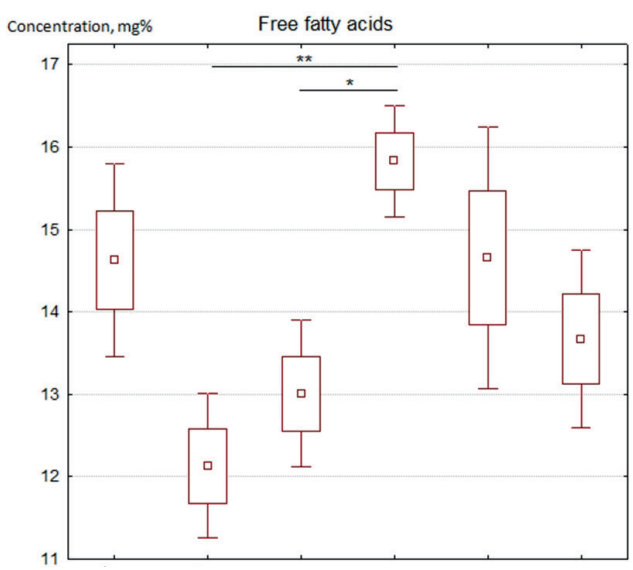

Fig. 4. The content of FFA in the bile of rats with PD, simulated by POT, before and after DP administrationthe. ${ }^{*} \mathrm{P}<0.05$, $* * \mathrm{P}<0.01 . \mathrm{M} \pm$ s.e.m. 
PL synthesis in hepatocytes under the influence of DP is a positive factor both for stabilizing the colloidal system of bile and preventing the accumulation of fat in the liver tissue.

In our study, we found that in rats with PD decreased the content of not only PL but also other bile lipids, including CHOL, ECHOL, and TG. CHOL can be absorbed from the intestine or synthesized de novo mainly in the liver. In this organ, CHOL is present in free form or the form of EHOL. CHOL is eliminated through its conversion into bile acids and their subsequent excretion with bile, either by secretion into bile in unchanged form or its esters form [24]. Although an excess of CHOL can be dangerous, its deficiency is also harmful to health because CHOL is a crucial compound that plays structural and functional roles in the general metabolism. In particular, CHOL is a component of cell membranes and plays a vital role in membrane fluidity, neuronal differentiation, synaptogenesis, and many other processes [25]. Thus, the normal metabolism of CHOL is crucial for maintaining the physiological functions of both the brain and the human body, and the liver is an organ that maintains the homeostasis of CHOL in the body. However, the debate over the lack of a link between serum CHOL and the risks of neurodegenerative diseases is ongoing. A high level of CHOL in the blood is a long-established risk factor for cardiovascular disease, including

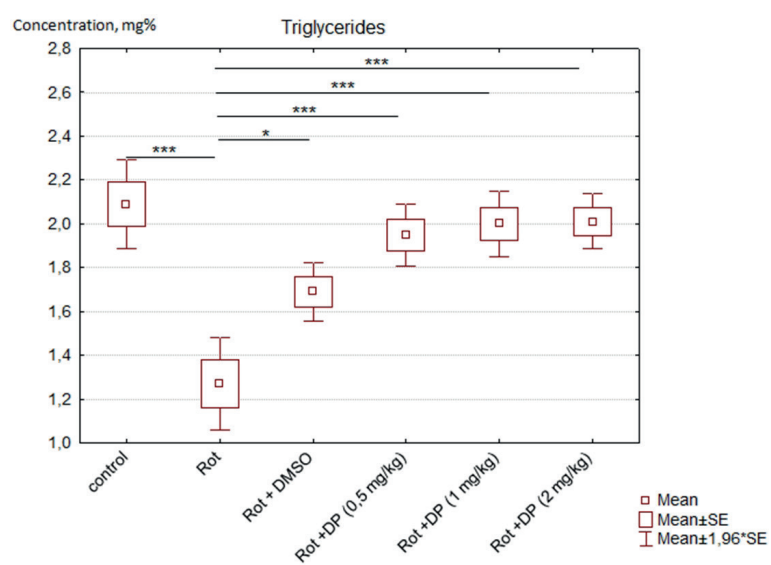

Fig. 5. Effect of DP on the content of TG in the bile of rats with ROT-modeled PD. $\mathrm{M} \pm$ s.e.m., $* \mathrm{P}<0.05, * * * \mathrm{P}<0.001$ coronary heart disease and stroke, but its role in parkinsonism remains controversial. On the one hand, there are attempts to link PD with high CHOL levels; on the other hand, no parallels have been drawn between alterations in $\mathrm{CHOL}$ metabolism and the development of PD [26]. In addition to free CHOL, bile contains ECHOLs, which are a soluble form of CHOL removal through the bile. Our results show that in rats with simulated PD, the level of ECHOL in the bile decreased almost twice, which may be due to a marked decrease in the CHOL synthesis in the liver in parkinsonian rats, and therefore decreased the number of its esterified molecules. We have previously shown a decrease in the concentration of CHOL and ECHOL in the plasma of rats with ROT-induced PD, as well as other plasma lipids, in particular PL, FFA, and TG [27]. Our experiments, at least for CHOL and TG, agree with the findings of other researchers who believe that the low content of these compounds in the plasma of patients with PD is a risk factor in its development [28]. The liver performs the functions of absorption, synthesis, packaging, and secretion of lipids and lipoproteins. For CHOL homeostasis in the body, TG is the most common non-toxic form of fatty acids. The source of liver FFA is fatty acids directly absorbed from plasma and synthesized by hepatocytes de novo. Excess FFA is directed to the synthesis of $\mathrm{TG}$, which increases their accumulation in the liver. TG molecules are the main form of storage and transport of FFA in cells and plasma. In hepatocytes, FFAs are esterified to glycerol-3-phosphate and CHOL to form TG or CHOL esters, respectively. FFA in the liver can also be used to synthesize other complex lipids, including PL. In conditions of an energy shortage, FFAs are used as an internal, local energy source [29]. A possible reason for the decrease in bile lipid content of Parkinsonic rats may be the increased use of FFA as an energy source to compensate for energy deficiency in conditions where the ATP-synthesizing function of mitochondria is blocked. 
The results of motor function investigation in rats with ROT-induced PD and the effect of DP on voluntary motility were published earlier [27].

\section{CONCLUSIONS}

We found that purine metabolic pathways play an essential role in the pathogenesis of Parkinson's disease induced by rotenone in rats. Cholesterol is a major component of brain structures; therefore, it is possible that low levels of this compound in patients with Parkinson's disease may be an increased risk of neurological disorders. Decreased synthesis of phospholipids in the liver in Parkinson's disease can lead to disruption of several physiological processes in this organ, in particular, such as the preservation of normal solubilizing properties of bile. We also found that the new drug diazepinone restores the level of lipids in the bile of rats by improving the energy balance in the liver because it increases the synthesis of ATP in hepatocytes. Diazepinone may be recommended for clinical trials regarding its use in combination with other drugs applying to treat Parkinson's disease. A significant and long-term decrease in the content of lipid components of bile, in our opinion, can be considered a diagnostic marker of Parkinson's disease.

Acknowledgments. The work was performed within the research of the Department of Organic Chemistry Faculty of Chemistry, the Taras Shevchenko National University of Kyiv on the topic "Promising molecular tools based on natural and synthetic (carbo) heterocycles to solve problems of chemistry, medicine, industry," No. $0119 U 100340$ (2019-2021).

The authors of this study confirm that the research and publication of the results were not associated with any conflicts regarding commercial or financial relations, relations with organizations and/or individuals who may have been related to the study, and interrelations of co-authors of the article.

Л.Я. Штанова ${ }^{1,2}$, П.І. Янчук ${ }^{1}$, С.П. Весельський ${ }^{1,2}$, О.В. Цимбалюк ${ }^{1}$, Т.В. Вовкун ${ }^{2}$, В.С. Москвіна ${ }^{2}$, О.В. Шабликіна ${ }^{2}$, В. М. Бабан $^{1,2}$, А.А. Кравченко ${ }^{3}$, В.П. Хиля ${ }^{2}$

КОРИГУЮЧА ДІЯ ПОХІДНОГО БЕНЗО-
ДІАЗЕПННУ ДІАЗЕПІНОНУ НА ПУРИНО-
ВИЙ ТА ЛІПІДИЙ ОБМІН У ПЕЧІНЦІ
ЩУРІВ 3 ХВОРОБОЮ ПАРКІНСОНА

${ }^{1}$ Інститут високих технологій Київського національного університету імені Тараса Шевченка;

${ }^{2}$ Київський національний університет імені Тараса Шевченка;

${ }^{3}$ Інститут хімії поверхні ім. О.О. Чуйка;Київ; e-mail:shtanova@ukr.net

Хвороба Паркінсона (ХП) - нейродегенеративний розлад, що характеризується типовими порушеннями моторики, спричиненими втратою дофамінергічних нейронів у substantia nigra. Причини цієї хвориби до кінця не 3'ясовані, ефективних методів лікування не існує. Вважається, що окисний стрес, дисфункція мітохондрій, порушення ліпідного обміну можуть лежати в основі патогенезу ХП. Жовч містить продукти розпаду різних сполук, які утворюються в гепатоцитах. Метою нашого дослідження було оцінити вплив нового похідного бензодіазепіну діазепінону на метаболізм пуринів та ліпідів у печінці щурів із ХП, спричиненими дією ротенону, вивчаючи склад жовчі. Концентрацію АТФ, АДФ, АМФ, ксантину, гіпоксантину, фосфоліпідів, холестерину, складних ефірів холестерину, вільних жирних кислот (ВЖК) та тригліцеридів визначали кількісно у зразках жовчі методом тонкошарової хроматографії. Отримані результати свідчать, що співвідношення АМФ/АТФ під впливом ротенону зросло майже втричі, а 3 діазепіноном воно перевищувало норму лише в 1,6 раза. Дія ротенону також збільшувала вміст ксантину та гіпоксантину на 28,6 і 66,7\% відповідно. Діазепінон не впливав на збільшений щодо контролю вміст ксантину, проте значно зменшував вміст гіпоксантину (до 22,2\%). Крім зазначеного, дія ротенону вірогідно зменшувала вміст у жовчі фосфоліпідів, холестерину, ефірів холестерину, тригліцеридів на 23,9, 38,6, 47,5, 39,2\% відповідно. При дії діазепінону всі вищеназвані показники повернулися до рівня контролю. Таким чином, він покращував як обмін пуринів, так і ліпідів у печінці щурів з ХП. Цей препарат у майбутньому може стати терапевтичним засобом для лікування ХП та, можливо, інших нейродегенеративних захворювань.

Ключові слова: ротенон; хвороба Паркінсона; печінка; метаболізм пуринів; метаболізм ліпідів; жовч. 
Л. Я. Штанова, П. И. Янчук, С. П. Весельский, О. В. Цимбалюк, Т. В. Вовкун, В. С. Москвина, О. В. Шабликина, А. А. Кравченко, В. Н. Бабан, В. П. Хиля

\section{КОРРЕКТИРУЮЩЕЕ ДЕЙСТВИЕ ПРОИЗВОДНОГО БЕНЗОДИАЗЕПИНА - ДИАЗЕПИНОНА НА ПУРИНОВЫЙ И ЛИПИДНЫЙ ОБМЕН В ПЕЧЕНИ КРЫС С БОЛЕЗНЬЮ ПАРКИНСОНА}

Болезнь Паркинсона (БП) - нейродегенеративное расстройство, характеризующееся типичными нарушениями моторики, вызванными потерей дофаминергических нейронов в substantia nigra. Причины этого заболевания до конца не выяснены, эффективных методов лечения не существует. Считается, что окислительный стресс, дисфункция митохондрий, нарушение липидного обмена могут лежать в основе патогенеза БП. Желчь содержит продукты распада различных соединений, которые образуются в гепатоцитах. Целью нашого исследования было изучить влияние нового производного бензодиазепина диазепинона на метаболизм пуринов и липидов в печени крыс с БП, вызванной действием ротенона, изучая состав желчи. Концентрацию АТФ, АДФ, АМФ, ксантина, гипоксантина, фосфолипидов, холестерина, сложных эфиров холестерина, свободных жирных кислот (СЖК) и триглицеридов определяли количественно в образцах желчи методом тонкослойной хроматографии. Полученные результаты свидетельствуют, что соотношение АМФ/АТФ выросло почти втрое под влиянием ротенона, с диазепиноном оно превышало норму лишь в 1,6 раза. Он также увеличивал содержание ксантина и гипоксантина на 28,6 и $66,7 \%$ соответственно. Диазепинон не влиял на увеличенное относительно контроля содержание ксантина, однако значительно уменьшал содержание гипоксантина (до $22,2 \%$ ). Кроме указаного, действие ротенона уменьшало содержание в желчи фосфолипидов, холестерина, эфиров холестерина, триглицеридов на 23,9, 38,6, 47,5, $39.2 \%$ соответственно. При действии диазепинона все вышеназванные показатели вернулись к уровню контроля. Таким образом, диазепинон может улучшать как обмен пуринов, так и липидов в печени крыс с БП. Данный препарат в будущем может стать терапевтическим средством для лечения БП и, возможно, других нейродегенеративных заболеваний.

Ключевые слова: ротенон; болезнь Паркинсона; печень; метаболизм пуринов; метаболизм липидов; желчь.

\section{REFERENCES}

1. Chen Ch, Turnbull D, Reeve A. mitochondrial dysfunction in parkinson's disease-cause or consequence? Biology (Basel). 2019;8(2):38.

2. Jenner P. Parkinson's disease, pesticides and mitochondrial dysfunction. Trends Neurosci. 2001;24(5):245-7.
3. Betarbet R, Sherer T, MacKenzie G, Garcia-Osuna M, Panov A, Greenamyre J. Chronic systemic pesticide exposure reproduces features of Parkinson's disease. Nat Neurosci. 2000;3:1301-6.

4. Cabreira V, Massano J. Parkinson's Disease: Clinical Review and Update. Acta Med Port. 2019 Oct;32(10):661670. https://doi.org/10.20344/amp.11978.

5. Connolly B, Lang A. Pharmacological treatment of Parkinson disease: a review. JAMA. 2014;311:1670-83.

6. Xicoy H, Wieringa B, Martens G. The role of lipids in Parkinson's disease. Cells. 2019;8(1):27.

7. Lei S, Zavala-Flores L, Garcia-Garcia A, Nandakumar R, Huang Y, Madayiputhiya N, Stanton R, Dodds E, Powers R, Franco R. Alterations in energy/redox metabolism induced by mitochondrial and environmental toxins: a specific role for glucose-6-phosphatedehydrogenase and the pentose phosphate pathway in paraquat toxicity. AC S Chem Biol. 2014;9(9):2032-2048.

8. Bernheimer H, Birkmayer W, Hornykiewicz O, Jellinger $\mathrm{K}$, Seitelberger F. Brain dopamine and the syndromes of Parkinson and Huntington. Clinical, morphological and neurochemical correlations. Neurol Sci. 1973;20(4):41555. doi:10.1016/0022-510x(73)90175-5.

9. Fonseca-Fonseca L, Wong-Guerra M, Ramírez-Sánchez J, Montano-Peguero Y, Padrón Yaquis A, Rodríguez A, da Silva V, Costa S, Pardo-Andreu Y. JM-20, a novel hybrid molecule, protects against rotenone-induced neurotoxicity in experimental model of Parkinson's disease. Neurosci Lett. 2019;690:29-35.

10. Shablykina O, Krekhova O, Konovalenko A, Moskvina V, Khilya V. Interaction of 3-pyridyland 3-(imidazo[1,2-a] pyridin-2-yl) isocoumarins with hydrazine. Dopov Nac Akad Nauk Ukr. 2018;(12):71-8.

11. Zeng X, Geng W, Jia J. Neurotoxin induced animal models of Parkinson disease: Pathogenic mechanism and assessment. ASN Neuro. 2018;10:1759091418777438.

12. Vovkun T, Yanchuk P, Shtanova L, Veselsky S, Filimonova N, Komarov I. Corvitin modulates the content of lipids in rat liver bile. Ukr Biochem J. 2019;91(6):112-121.

13. Bonora M, Patergnani S, Rimessi A, De Marchi E, Suski J, Bononi A, Giorgi C, ATP synthesis and storage. Purinergic Signal. 2012;8(3):343-357.

14. Higgins D, Greenamyre J. [3H]dihydrorotenone binding to NADH: ubiquinone reductase (complex I) of the electron transport chain: an autoradiographic study. J Neurosci. 1996 June 15;16(12):3807-16.

15. Palmer G, Horgan D, Tisdale H, Singer T, Beinert H. Studies on the respiratory chain-linked reduced nicotinamide adenine dinucleotide dehydrogenase. XIV. Location of the sites of inhibition of rotenone, barbiturates, and piericidin by means of electron paramagnetic resonance spectroscopy. J Biol Chem. 1968;243(4):844-7.

16. Schapira A. Mitochondria in the aetiology and pathogenesis of Parkinson's disease. Lancet Neurol. 2008;7:97-109.

17. Hernández-Muñoz R, Glender W, Díaz-Muñoz M, Suárez J, Lozano J, Chagoya de Sánchez V. Alterations of ATP 
levels and of energy parameters in the blood of alcoholic and nonalcoholic patients with liver damage. Alcohol Clin Exp Res. 1991;15(3):500-3.

18. Sherer T, Betarbet R, Testa C, Seo B, Richardson J, Kim J, Miller G, Yagi T, Matsuno-Yagi A, Greenamyre J. Mechanism of toxicity in rotenone models of Parkinson's disease. J Neurosci. 2003 Nov 26;23(34):10756-64.

19. Yakhine-Diop S, Morales-García J, Niso-Santano M, González-Polo R, Uribe-Carretero E, Martinez-Chacon G, Durand S, Maiuri M, Aiastui A, Zulaica M, RuízMartínez J, de Munain A, Pérez-Tur J, Pérez-Castillo A, Kroemer G, Bravo-San Pedro J, Fuentes J. Metabolic alterations in plasma from patients with familial and idiopathic Parkinson's disease. Aging (Albany NY). 2020;12(17):16690-708.

20. El Ridi R., Tallima H. Physiological functions and pathogenic potential of uric acid: A review. J Adv Res. 2017;8:487-93.

21. Morita S, Ikeda Y, Tsuji T, Terada T. Molecular mechanisms for protection of hepatocytes against bile salt cytotoxicity. Chem Pharm Bull (Tokyo). 2019;67(4):333340.

22. Lamont J, Carey M. Cholesterol gallstone formation. 2. Pathobiology and pathomechanics. Prog Liver Dis. 1992;10:165-91.
23. Rossmeisl M, Medrikova D, van Schothorst E, Pavlisova J, Kuda O, Hensler M, Bardova K, Flachs P, Stankova B, Vecka M, Tvrzicka E, Zak A, Keijer J, Kopecky J. Omega-3 phospholipids from fish suppress hepatic steatosis by integrated inhibition of biosynthetic pathways in dietary obese mice. Biochim Biophys Acta. 2014;1841(2):267-78.

24. Cohen D. Hepatocellular transport and secretion of biliary lipids. Current Opin Lipid. 1999;10(4):295-302.

25. Zhang J, Liu Q. Cholesterol metabolism and homeostasis in the brain. Protein Cell Springer. 2015;6:254-64.

26. Gudala K, Bansal D, Muthyala H. Role of serum cholesterol in Parkinson's disease: a meta-analysis of evidence. J Parkinsons Dis. 2013;3:363-70.

27. Shtanova L, Yanchuk P, Veselsky S, Tsymbalyuk O, Vovkun T, Moskvina V, Shablykina O, Bogza S, Baban V, Kravchenko A, Khily V. Diazepinone effect on liver tissue respiration and serum lipid content in rats with a rotenone model of Parkinson's disease. ISSN 2409-4943. Ukr Biochem J. 2020;92(6):85-94.

28. Fang F, Zhan Y, Hammar N, Shen X, Wirdefeldt K, Walldius G, Mariosa D. Lipids, apolipoproteins, and the risk of Parkinson's disease. Circ Res. 2019;125(6):643-52.

29. Alves-Bezerra M, Cohen D. Triglyceride Metabolism in the Liver. Compr Physiol. 2017 Dec 12;8(1):1-8. 